УДК: 377.011.3-051:[005.966:004

\title{
РОЗВИТОК ІНФОРМАЦІЙНО-АНАЛІТИЧНОЇ КОМПЕТЕНТНОСТІ ПЕДАГОГІЧНИХ ПРАЦІВНИКІВ ЗАКЛАДІВ ПРОФЕСІЙНОЇ (ПРОФЕСІЙНО-ТЕХНІЧНОӦ) ОСВІТИ
}

\author{
Лідія Гуменна, \\ молодший науковий співробітник лабораторії \\ електронних навчальних ресурсів \\ Інституту професійно-технічної освіти \\ НАПН Украӥни \\ ORCID: 0000-0003-3813-5894
}

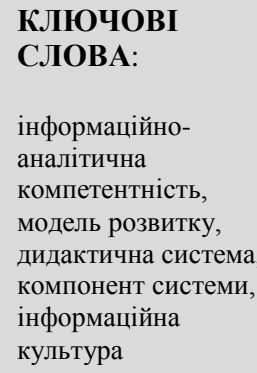

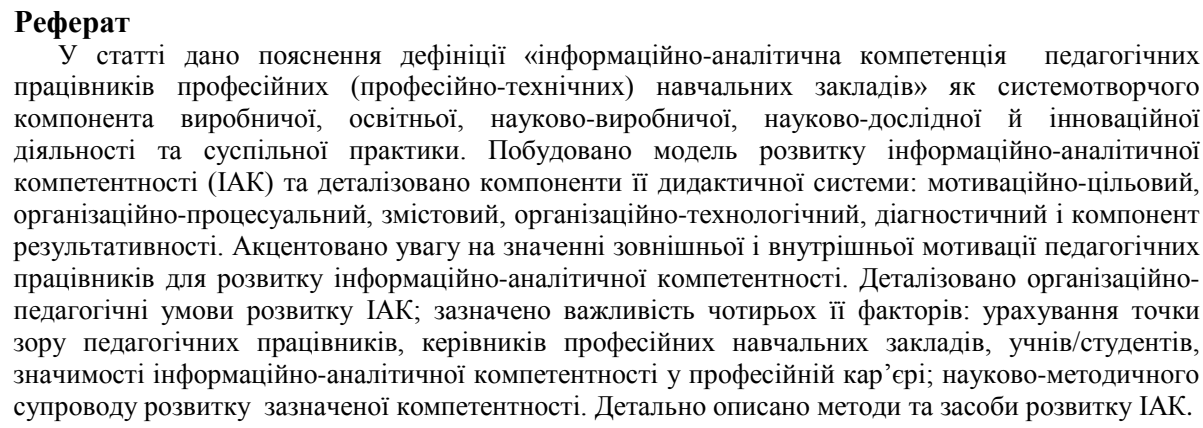

У статті дано пояснення дефініції «інформаційно-аналітична компетенція педагогічних працівників професійних (професійно-технічних) навчальних закладів» як системотворчого компонента виробничої, освітньої, науково-виробничої, науково-дослідної й інноваційної діяльності та суспільної практики. Побудовано модель розвитку інформаційно-аналітичної компетентності (IAK) та деталізовано компоненти іiі дидактичної системи: мотиваційно-цільовий, організаційно-процесуальний, змістовий, організаційно-технологічний, діагностичний і компонент результативності. Акцентовано увагу на значенні зовнішньої і внутрішньої мотивації педагогічних працівників для розвитку інформаційно-аналітичної компетентності. Деталізовано організаційнопедагогічні умови розвитку IAК; зазначено важливість чотирьох іiі факторів: урахування точки зору педагогічних працівників, керівників професійних навчальних закладів, учнів/студентів, значимості інформаційно-аналітичної компетентності у професійній кар'єрі; науково-методичного супроводу розвитку зазначеної компетентності. Детально описано методи та засоби розвитку ІАК.

\section{Постановка проблеми. Сучасне} суспільство є інформаційним і щоразу ставить нові вимоги як до системи професійнотехнічної освіти, так і до професійної діяльності іiі суб'єктів. Саме тому у функціонуванні конкретних професійнотехнічних навчальних закладів має постійно враховуватися, 3 одного боку, необхідність досконалого володіння фахівцями сучасними інформаційними технологіями, а 3 іншого швидке старіння наукових знань, різноманітної навчальної та службової інформації, інформаційних технологій тощо. Це, безумовно, має істотний уплив, по-перше, як на всіх суб'єктів системи професійної (професійно-технічної) освіти, серед яких $\epsilon$ особлива категорія - педагогічні працівники, так і на модернізацію професійної освіти та складові професійної підготовки майбутніх фахівців у закладах професійної (професійнотехнічної) освіти (далі-ЗП(ПТ)О).

Однак незаперечні досягнення у сфері методичної роботи щодо розвитку інформаційно-аналітичних теоретичних і технологічних знань, умінь i навичок педагогічних працівників професійнотехнічних навчальних закладів, подальший цілеспрямований розвиток цієї діяльності стримується недостатньою вирішеністю завдань розроблення теорії i методики розвитку їхньої інформаційно-аналітичної компетентності - складової інформаційної культури.

Аналіз останніх досліджень. Проблеми розвитку компетентності (IAK) на загальних теоретичних та методологічних засадах модернізації ПО розглядалися Р. Гуревичем, Н. Кузьміною, Н. Ничкало, В. Радкевич та ін.; 3 позиції теоретичних основ формування професійної компетентності педагогічних працівників у системі підготовки кваліфікованих робітників - В. Адольфом, Е. Зеєром, С. Коваленком, Н. Кузьміною, Т. Браже, М. Ільїним, Г. Ібрагімовим, Е. Помиткіним, С. Шишовим та ін.; 3 інформаційно-аналітичного забезпечення органів управління професійно-технічною освітою різних рівнів досліджували О. Гуменний, Л. Петренко, І. Савченко; 3 точки зору підвищення інформаційноаналітичної компетентності педагогічних працівників різних освітніх рівнів Н. Гайсинюк, Н. Величко, Л. Забродська, Н. Зінчук, О. Назначило, В. Омельченко, Ю. Сурмін, В. Ягупов та ін.; 3 упровадження сучасних інформаційно-комунікативних технологій у процес підготовки фахівців 
Лідія Гуменна. Розвиток інформаційно-аналітичної компетентності педагогічних працівників закладів професійної (професійно-технічної) освіти

досліджувалися О. Григор'євою,

М. Жалдаком, Г. Селевком, С. Сисоєвою, О.Спіріним, О. Тарасенко, Л. Тучкіною, В. Фоміним, Л. Шелеховою та ін.

Мета статті - відобразити й деталізувати модель розвитку інформаційно-аналітичної компетентності педагогічних працівників закладів П(ПТ)О та ii реалізацію для покращення освітньої діяльності.

Виклад основного матеріалу. У сучасному інформаційному суспільстві найважливішими завданнями $\epsilon$ отримання, розроблення та поширення освітніх, наукових i культурних відомостей, збереження кожною нацією своєї історичної спадщини та ідентичності, постійне й систематичне забезпечення високої якості освіти. Для цього важливо педагогам, а, отже, й педагогічним працівникам професійних навчальних закладів, розвивати латеральне мислення - непрямого та творчого підходу для вирішення освітніх проблем, що відображається на здатності до аналітикосинтетичного опрацювання інформації, рефлексії, вироблення правильного рішення у навчально-виховній діяльності, швидкої адаптації у разі постійних змін і нестандартних ситуацій. Сприймаючи події по-новому, вони мислять іншими категоріями, а тому змінюється й мотивація діяльності, відбувається пошук технологій досягнення більш високих результатів за короткі терміни i 3 мінімальними зусиллями. Володіння фахівцями сучасними інформаційними технологіями уможливлює ефективне використання інформаційних ресурсів, а саме: оптимізовувати та автоматизовувати інформаційні процеси, розробляти навчальновиробничі технології, задіювати системи електронних телекомунікацій для підвищення якості навчального матеріалу. Застосування інноваційних педагогічних програм і методик підсилює освітні ефекти, оскільки дає педагогічним працівникам додаткові можливості для побудови індивідуальних освітніх траєкторій студентів/учнів, реалізації диференційованого підходу 3 урахуванням рівня їхньої готовності до навчання, організації різних форм навчальнопізнавальної діяльності на заняттях, активізації й цілеспрямування самостійної роботи учнів тощо. На сайті коледжу Баддін
[1](Bowdoin College), Брауншвейг, штат Мен, зазначено: системне й логічне вирішення проблеми, виявлення причинно-наслідкових зв'язків i передбачення несподіваних результатів; їх розв'язання з позиції власного досвіду і знань, а також використання інших ресурсів - у разі необхідності - $\epsilon$ інформаційно-аналітичною компетентністю.

Інформаційно-аналітична

компетентність, на нашу думку, - це системотворчий компонент виробничої, освітньої, науково-виробничої, науководослідної й інноваційної діяльності та суспільної практики. Важливою пї особливістю $є$ сприяння розвитку латерального мислення.

Без інформаційно-аналітичної компетентності, як стверджує В. Ягупов, неможливо дотримуватися ключових принципів інформаційного суспільства: забезпечення загального та вільного доступу громадян до інформаційних й комунікаційних інфраструктур i технологій, відомостей i знань; підвищення довіри й безпеки при використанні IКТ з акцентуванням уваги на етичних аспектах[2].

Розвиток IAK педагогічних працівників професійних навчальних закладів є процесом реалізації інноваційної діяльності, спрямованої як об'єктивно, так і суб'єктивно на новий (для конкретного педагогічного працівника) результат. Тому цей процес доцільно розглядати як повний, завершений цикл продуктивної діяльності, що має бути реалізований у «певній часовій послідовності, за фазами, стадіями й етапами (часова структура організації діяльності)» [3, с. 8].

Узявши за основу гносеологічний i загальнометодичний аспекти теорії моделювання, теорії систем та основні компоненти практичної діяльності, нами розроблено модель розвитку IAK педагогічних працівників професійнотехнічних навчальних закладів (рис. 1). При побудові моделі зроблено припущення, що розвиток інформаційно-аналітичної компетенції педагогічних працівників, здійснюваний усвідомлено й контрольовано, сприяє досягненню позитивного результату динаміки всіх компонентів цього складного поліфункціонального утворення як складової професіоналізму 


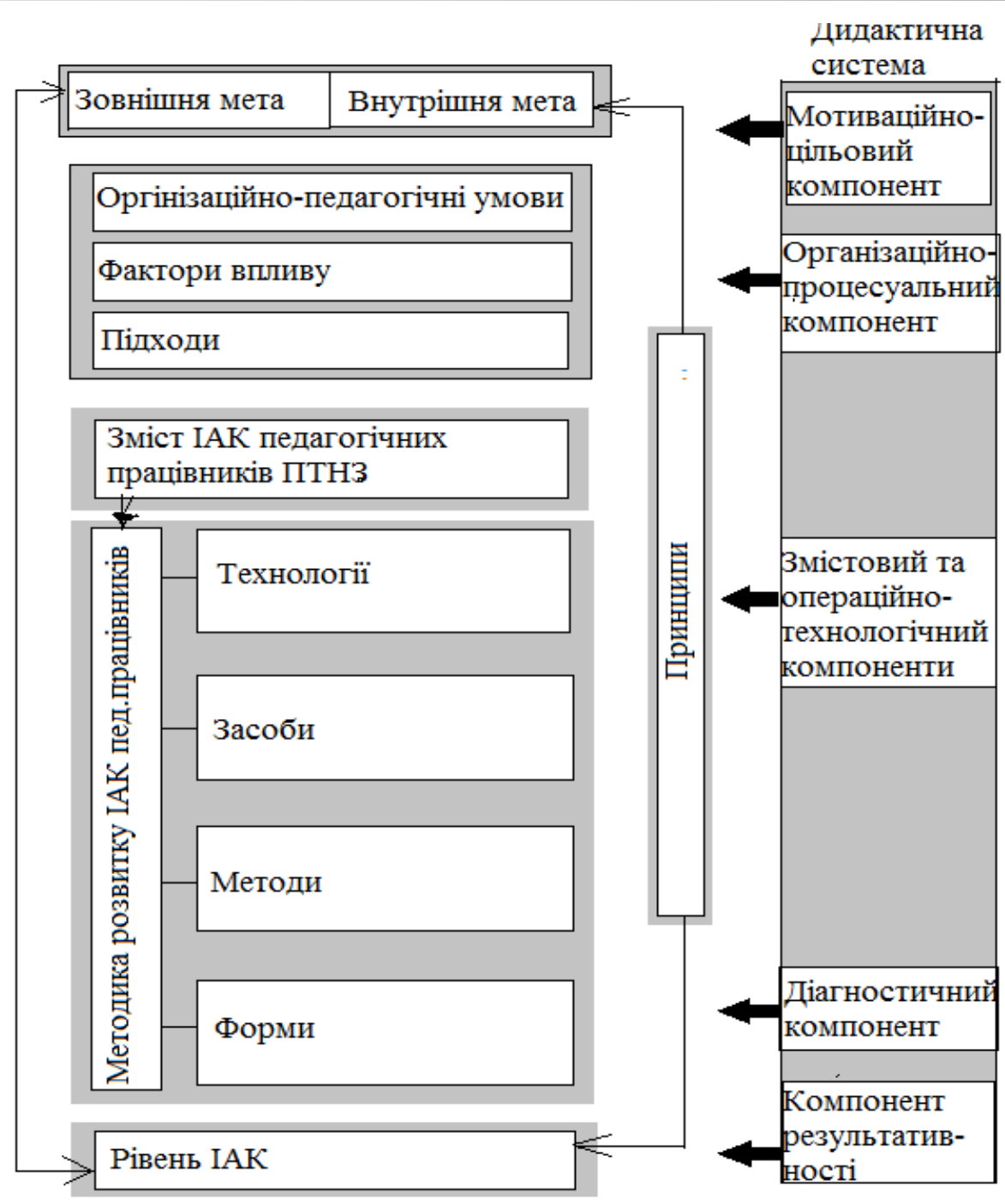

Puc.1.

Модель розвитку інформаичійно-аналітичної компетентності педагогічних праиівників закладів П(ПТ)О

Уточнимо елементи представленої моделі. Зовнішня іiі мета: розвиток інформаційно-аналітичної компетентності педагогічних працівників за вимогами інформаційного суспільства. Внутрішня розвиток інформаційно-аналітичної компетентності педагогічних працівників ЗП(ПТ)О для вдосконалення професійної діяльності.

Організаційно-педагогічні умови: організація методичної роботи, самоосвіта, відбір змісту розвитку інформаційноаналітичної компетентності, розроблення навчально-методичного забезпечення, науково-методичний супровід.
Фактори впливу: педагогічний стаж, психологічні особливості; зовнішня та внутрішня мотивація.

Підходи: андрагогічний; компетентнісний; особистісно-орієнтований.

Зміст: розвиток інформаційноаналітичної компетентності педагогічних працівників ЗП(ПТ)О: інформаційноаналітичні теоретичні та технологічні знання; комунікаційні, аналітичні та синтезуючі уміння й навички; спрямованість і мотивація особистості на інформаційно-аналітичну діяльність.

Методика розвитку інформаційноаналітичної компетентності педагогічних працівників ЗП(ПТ)О: 
- технології: Web-технологія, майстерклас, е-портфоліо;

- засоби: ментальні карти, е-каталоги, е-щоденники, інформаційні та інформаційноаналітичні системи, експертні системи, системи інформаційного обслуговування;

- методи: рефлексія, дослідницький, самостійна діяльність, репродуктивний, проектна діяльність;

- форми: очна (тренінги, семінари, бар-хамп, лекції, індивідуальні та групові консультаціі, дистанційна (вебінари, воркшопи, індивідуальна та групова робота в LMS).

Моніторинг рівня інформаційноаналітичної компетентності педагогічних працівників 3П(ПТ)О - базовий, поглиблений, професійний.

Принципи:

актуальність; активність; достовірність; змістовність; альтернативність; обгрунтованість; системність; своєчасність; ініціативність; об'єктивність; безперервність.

Згідно розробленої моделі, іiі мотиваційно-иільовий компонент складається iз зовнішньої та внутрішньої мотивації.

Зовнішня мотивація розвитку інформаційно-аналітичної компетентності зумовлена соціальним замовленням інформаційного суспільства. Один із засновників концепції інформаційного суспільства (або постіндустріального) Д. Белл у процесі його аналізу особливу увагу звертав на соціальні чинники, наголошуючи, що в XXI ст. вирішальне значення для економічного та соціального життя, виробництва знань, а також характеру трудової діяльності матиме такий новий соціальний лад, який грунтується на телекомунікаціях [4]. Внутрішньою є мотивація розвитку ІАК педагогічних працівників для: вдосконалення власної професійної діяльності; врахування інтенсивності конкурентоспроможності на ринку праці; кар'єрного зростання; підвищення категорії під час проходження атестації; отримання надбавок за інноваційну діяльність тощо.

Організаційною структурою дидактичної системи моделі є організаційно-процесуальний компонент (ОПК) розвитку ІАК педагогічних працівників професійно-технічних навчальних закладів. Значимими елементами зазначеного компоненту $є$ організаційнопедагогічні умови, фактори впливу і підходи.

Організаційно-педагогічними умовами (ОПК) є організація методичної роботи, впровадження в систему підвищення кваліфікації науково-обгрунтованої багаторівневої та багатокомпонентної моделі розвитку ІАК; вибір форм i методів, адекватних професійному i життєвому досвіду педагогічного працівника, диференціація та інтеграція змісту; розроблення індивідуального плану саморозвитку; відбір контент-змісту для безперервного розвитку інформаційноаналітичної компетентності на основі власного електронного освітнього середовища. При цьому важливо брати до уваги чотири точки зору - самого педагогічного працівника, його керівника, учнів/студентів, колег; розроблення електронного навчально-методичного забезпечення; науково-методичний супровід.

Факторами впливу зазначеного компонента моделі $€$ : педагогічний стаж; психологічні особливості; мотивація, а також підходи - андрагогічний, компетентнісний та особистісно-орієнтований.

Компоненти - операційно-технологічний та змістовий - складаються із технологій, засобів, методів і форм.

Серед сучасних технологій заслуговують на особливу увагу Web-технологія - як сукупність методів та програмно-технічних засобів, інтегрованих 3 метою ефективного опрацювання вебресурсів, що знаходяться у веб-просторі; майстер-класи, метою яких $\epsilon$ тренування розумових здібностей, логічного інтелекту i вербальних навичок у процесі комунікації з тренером та в групі; е-потрфоліо - набір матеріалів в електронному варіанті 3 динамічною інформацією, що демонструє інформаційно-аналітичні, теоретичні й технологічні знання, вміння, навички i здатність вирішувати завдання навчальновиховного спрямування у професійній діяльності.

Засоби: ментальні карти (інтелект-карти, карти розуму, карти пам'яті, Mind Maps) зображення процесу загального системного мислення за допомогою схем; е-каталоги каталог на електронному носії, що подає переважно зміст паперового каталогу та містить інформацію про підвищення 
доступності та якості освіти, забезпечення можливості дистанційного, індивідуального навчання, самоосвіти та систематизації досвіду використання електронних освітніх ресурсів у професійних навчальних закладах; е-щоденники - система 3 інформацією про електронні щоденники учнів/студентів, відвідування ними навчального закладу, розклад, про педагогічних працівників, адміністрацію, контактні дані тощо; інформаційно-аналітичні системи: інформаційно-аналітична система Державної науково-педагогічної бібліотеки України імені В. О. Сухомлинського, Інституту освітньої аналітики тощо; експертні системи інформаційні системи автоматизації процесів прийняття рішень, створені на основі опрацювання вибірок статистичних даних, або в яких використовуються експертні оцінки. Експертні системи є різновидністю систем комп'ютеризованої підтримки прийняття рішень, в яких поєднується комплексне використання експертних оцінок та результатів аналітичного опрацювання даних[5, с. 5]; системи інформаційного обслуговування - бібліотечно-інформаційна система, спрямована на вирішення проблеми інформаційного забезпечення професійного навчального закладу сучасними інструментами інформаційного опрацювання через налагодження на новій основі бібліотечно-інформаційного обслуговування всіх суб'єктів навчально-виховного процесу, автоматизовані робочі місця (APM) педагогічних працівників тощо.

Методи: рефлексія - пов'язана 3 необхідністю фіксації зупинки і самого процесу 3 метою виділення проблеми [6]. Саме через фіксацію реалізується ставлення суб'єкта до предмета рефлексії, відбувається поляризація рефлексивного процесу, що приводить до глибшого усвідомлення проблеми. Аналіз як наступний етап рефлексивного процесу може набувати форми внутрішнього діалогу, рішення, висновків або наміру діяти певним чином. Розвиток педагогічної рефлексії у ході професійнопедагогічної підготовки виявляється в глибині переосмислення педагогічним працівником власного досвіду та характеризується особистим внеском в організацію інформаційно-аналітичного росту, потребою особистості у вільному вибору змісту діяльності, способів іiі розширення i поглиблення [7]. Важливого методологічного значення набуває положення про взаємозв'язок творчої та пізнавальної діяльності 3 рефлексією, що спрямована на розвиток самосвідомості, на осмислення й орієнтацію дій суб'єкта (інтелектуальна рефлексія), на самоорганізацію, рух через самопізнання, самоаналіз стану - внутрішніх психічних актів, власних форм і передумов, розумової діяльності, цілісного «Я» (особистісна рефлексія) та через осмислення діяльності учнів/студентів у спілкуванні; взаємовідображення суб'єктів (міжособистісна рефлексія); дослідницький 3 питань інформаційної аналітики (консолідована інформація) розробки моделей i алгоритмів, інформаційно-аналітичних систем підтримки педагогічних процесів, розробки технологій i методів побудови інтелектуальних інформаційно-аналітичних SMART-комплексів для підготовки майбутніх конкурентноздатних фахівців; самостійна діяльність за методикою, розробленою О. Назначило, що передбачає поетапну роботу викладача 3 модулями: самостійну роботу до заняття, спільну і самостійну роботу під час занять та самостійну робота після занять. У процесі дослідження вченою було виявлено, що «матеріал інформаційного блоку відтворюється тим легше, чим більше він пов'язаний 3 практикою безпосереднього здійснення інформаційно-аналітичної діяльності викладача»[8, с.123]. У процесі інтенсивної інтелектуальної праці педагогічного працівника збільшуються його інформаційно-аналітичні уміння й накопичується досвід; репродуктивний, спрямований на відтворення педагогічним працівником способів інформаційноаналітичної діяльності за визначеним алгоритмом; проектна діяльність, метод проектів - педагогічна технологія, в якій поєднується сукупність дослідницьких, пошукових, проблемних методів, творчих за своєю суттю, що цілком відповідає поняттю «механізм». При цьому педагогічний працівник виконує роль куратора контенту змісту. Ця технологія сприяє розвитку пізнавальних навичок, умінь самостійно конструювати власні знання, орієнтуватися в інформаційному просторі, розвивати критичне i творче мислення, що відповідає основній меті моделі розвитку їхніх 
Лідія Гуменна. Розвиток інформаційно-аналітичної компетентності педагогічних працівників закладів професійної (професійно-технічної) освіти

інформаційно-комунікаційних

компетентностей.

Форми: очна та дистанційна.

Діагностичний компонент моделі розвитку ІАК педагогічних працівників професійно-технічних навчальних закладів визначає моніторинг рівня їхньої інформаційно-аналітичної компетентності. Структура означеної моделі передбачає оволодіння об'єктом навчання теоретичними i технологічними інформаційно-аналітичними та синтетичними знаннями, уміннями й навичками у процесі навчально-виховної діяльності. У педагогічній теорії та практиці доведено, що ефективність навчальновиховного процесу значною мірою визначається технологією навчального заняття $[9, \quad$ с. 115]. Тому педагогічному працівникові важливо обрати таку форму навчання, яка б дала змогу за відносно короткий час розв'язати відразу кілька завдань, організовуючи різноманітну діяльність учнів/студентів. При цьому необхідно врахувати специфіку їхньої категорії та умови, в яких відбувається навчання. Так, у ході розробки педагогічним працівником навчально-методичного комплексу (сукупність технічних, програмних i методичних засобів забезпечення самостійної роботи учнів/студентів, спрямованої на одержання i практичне використання актуальних науковотеоретичних, технічних i технологічних знань), зумовлюється поетапна послідовність реалізації моделі розвитку ІАК: визначаються цілі й завдання процесу навчання, в межах якого використовуватиметься електронний навчальний комплекс (визначення інформаційної потреби); уточнюються початкові знання і вміння учнів/студентів до початку навчального процесу 3 використанням електронного підручника (діагностика знань та вмінь); здійснюється пошук і аналіз аналогів програмних продуктів 3 обраної тематики - пошук інформації (iї аналіз потрібний для планування подальших дій); використовується наявний продукт або розробляється власний; здійснюється структурування змісту навчання згідно сформульованоїю мети; визначаються типи навчальних тренувальних завдань, розробляються схеми контролю знань (удосконалення умінь роботи з інформацією); генеруються схеми інтерфейсу i сценарії комплексу (перероблення інформації i створення нового знання); підготовляється текст теорії (якісно-кількісне опрацювання інформації), ілюстрації та мультимедіакомпоненти; реалізовується електронний комплекс; проводиться експертиза й апробація кожного компонента; оформляються деталізовані методичні рекомендації щодо організації та проведення навчального процесу 3 використанням електронного комплексу [10, с. 112-113]. Таким чином, діагностичний компонент моделі розвитку ІАК визначається створенням електронного комплексу, що потребує реалізації усіх його компонент.

Компонент результативності відображає базовий, поглиблений чи професійний рівень інформаційно-аналітичної компетентності педагогічного працівника за даними діагностичного компонента. Інформаційно-аналітичну діяльність вважають не тільки цілеспрямованим процесом, результативність якого забезпечує рівень сформованості умінь спеціаліста знаходити, оцінювати й використовувати у своїй професійній діяльності необхідну інформацію, а також уміння аналізувати i структурувати інформацію, володіти спеціальними методами іiі аналізу, «виконувати ï якісно-змістове перетворення, досліджувати i прогнозувати розвиток інформаційних процесів на основі формальних чи напівформальних моделей у межах сучасної соціально-економічної сфери діяльності людини.

Висновок. За умови створення та вдосконалення організаційно-педагогічних умов реалізації педагогічними працівниками професійно-технічних навчальних закладів відображеної та деталізованої моделі, уможливлюється розвиток їхньої інформаційно-аналітичної компетентості. Підвищення рівня ІАД виразиться через усвідомлення ролі інформації в житті індивіда, особи, фахівця, функціонування професійно-технічних навчальних закладів; знання й розуміння основних трактувань феномена інформації в інформаційному суспільстві та їх впливу на формування сучасної картини світу, на функціонування різних сфер суспільства i характер професійної діяльності педагогічних 
працівників у закладах П(ПТ)О; готовність і здатність враховувати у своїй професійнопедагогічній діяльності закономірності інформаційних процесів й особливості їх прояву; володіння навичками та вміннями аналізу, синтезу та оцінювання інформації з позицій іiі властивостей, професійної, практичної й особистісної значущості.

\section{Література}

1. Definition and Behavioral Indicators of Analytical Thinking/Problem Solving/ [Електронний pecypc]. - Режим доступу: https://www.bowdoin.edu/hr/manager-toolkit/PA7review-resources-competency-analyticalthinking.shtml. - Дата звернення: 17.06.2017.

2. Ягупов В. В. Чинники розвитку інформаційно-аналітичної компетентності педагогічних працівників професійно-технічних навчальних закладів / В. В. Ягупов // Професійне навчання на виробництві : [зб. наук. пр. / гол. ред. колегії Н. Ничкало]. - Київ : Вид-во ТОВ «ІМОпрес», 2016. - Вип. VI. - С. 130-142.

3. Новиков А. М. Методология: [монография] / А. М. Новиков, Д. А. Новиков. М.: СИНТЕГ, 2007. -663 c.

4. Белл Д. Грядущее постиндустриальное общество. Опыт социального прогнозирования / Д. Белл. - М. : Academia, 1999. - 786 с.

5. Нейлор К. Как построить свою экспертную систему: Пер. с англ. / Нейлор К. - М. : Энергоатомиздат, 1991, - 286 c.

6. Митина Л. М.

Психология профессионального развития учителя: [Текст] / Л. М. Митина. - М. : Флинта : Москов. психологосоциал. ин-т, 1998. -200 с.
7. Литвиненко С. Формування педагогічної рефлексії у процесі професійної підготовки майбутніх учителів в умовах ступеневої освіти / С. Литвиненко. - [Електронний ресурс]. - Режим доступу: http://irbis-nbuv.gov.ua/cgibin/irbis_nbuv/cgiirbis_64.exe?C21COM=2\&I21DBN $=$ UJRN\&P21DBN=UJRN\&IMAGE_FILE_DOWNL OAD=1\&Image_file_name=PDF/Npd_2013_1.2_4.pd f -Дата звернення: 17.06.2017.

8. Назначило Е. В.

Развитие информационно-аналитической компетентности преподавателя в процессе непрерывного педагогического образования: дис. ... канд. пед. наук: спец. 13.00.08 / Назначило Елена Валерьевна; Магнитогорский гос. ун-т. Магнитогорск, 2003. - 193 с.

9. Морева Н. А.

Технологии профессионального образования. Учеб. пособие для студ. высш. учеб. заведений / Н. А. Морева. М. : Академия, 2005. - 432 с.

10. Гайдамак Е. С.

Развитие информационно-аналитической компетентности будущего магистра физико-математического образования: дис. ... канд. пед. наук: 13.00 .02 / Гайдамак Елена Сергеевна; Омский гос. пед. ун-т. - Омск, 2006. - 214 с.

\section{Реферат}

\section{Развитие информационно-аналитической компетентности педагогических работников учреждений профессионального (профессионально-технического) образования}

\author{
Лидия Гуменная, \\ младиий научный сотрудник лаборатории \\ электронных учебных ресурсов \\ Института профессионально-технического образования \\ НАПН Украинь
}

КЛЮЧЕВЫЕ
СЛОВА:
профессиональное
образование,
информационно-
аналитическая
компетентность,
модель развития,
дидактическая
система, компонент
системы,
информационная
культура

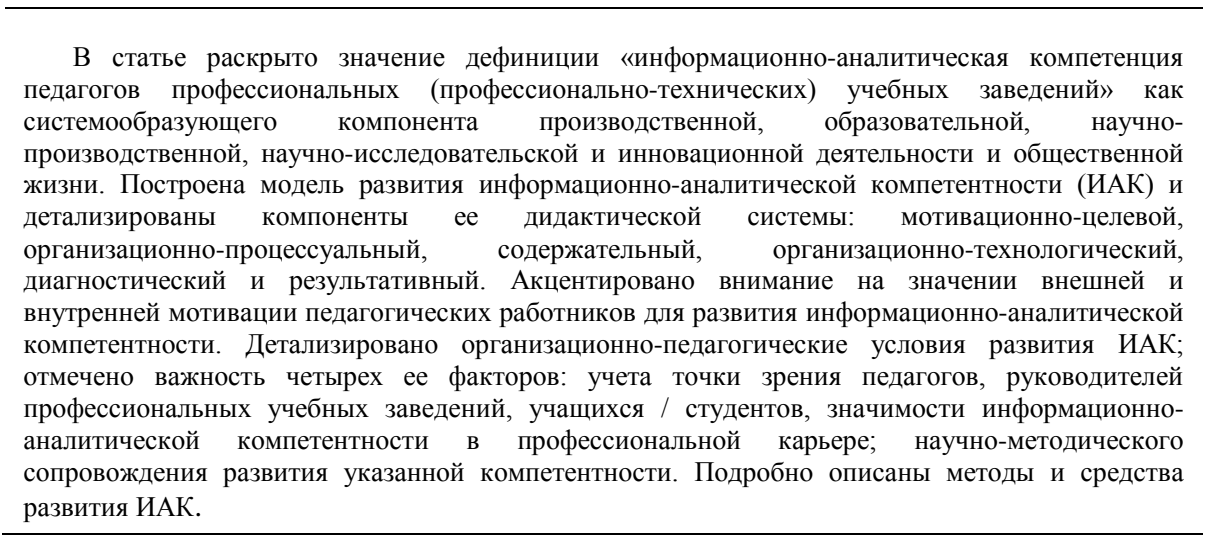


Лідія Гуменна. Розвиток інформаційно-аналітичної компетентності педагогічних працівників закладів професійної (професійно-технічної) освіти

\begin{tabular}{|c|c|}
\hline \multicolumn{2}{|c|}{$\begin{array}{r}\text { Abstract } \\
\text { Information-analy }\end{array}$} \\
\hline & $\begin{array}{l}\text { Lidiia Humenna } \\
\text { Junior researcher } \\
\text { Laboratory of e-learning resources } \\
\text { Institute of VET of NAES of Ukraine }\end{array}$ \\
\hline $\begin{array}{l}\text { KEY WORDS: } \\
\text { VET, information- } \\
\text { analytical competence, } \\
\text { development model, } \\
\text { system component, } \\
\text { didactic system, } \\
\text { information culture }\end{array}$ & $\begin{array}{l}\text { The article reveals explanation of the definition "VET institutions pedagogical staff } \\
\text { information-analytical competence" as a system-creating component for industry, education, } \\
\text { R\&D and manufacturing, research and innovative activity and social life sectors. The model } \\
\text { of information-analytical competence development is built and its didactic system } \\
\text { components are detailed: motivational-purpose, organizational-procedural, substantial, } \\
\text { organizational-technological, diagnostic and resultant. The attention is drugged to teachers' } \\
\text { inner and outer motivation importance for developing the information-analytical } \\
\text { competence. The organizationally-pedagogical terms for information-analytical competence } \\
\text { development are detailed; the importance of four factors is marked: considering point of } \\
\text { view of pedagogical workers, VET schools leaders, students on information-analytical } \\
\text { competence importance for professional life; scientifically-methodical support for the } \\
\text { following competence development. Methods and facilities for information-analytical } \\
\text { competence development are described in details. }\end{array}$ \\
\hline
\end{tabular}

\section{References}

1. Definition and Behavioral Indicators of Analytical Thinking/Problem Solving/ - [Elektronniy resurs]. $\quad$ - Rezhim dostupu: https://www.bowdoin.edu/hr/manager-toolkit/PA7review-resources-competency-analyticalthinking.shtml. - Data zvernennya: 17.06.2017.

2. Yahupov V. V. Chynnyky rozvytku informatsiino-analitychnoi kompetentnosti pedahohichnykh pratsivnykiv profesiino-tekhnichnykh navchalnykh zakladiv / V. V. Yahupov // Profesiine navchannia na vyrobnytstvi : [zb. nauk. pr. / hol. red. kolehii N. Nychkalo]. - Kyiv : Vyd-vo TOV «IMOpres», 2016. - Vyp. VI. - S. 130-142.

3. Novikov A. M. Metodologiya: [monografiya] / A. M. Novikov, D. A. Novikov. - M. : SINTEG, 2007. - 663 s.

4. Bell D. Gryaduschee postindustrialnoe obschestvo. Opyit sotsialnogo prognozirovaniya / D. Bell. - M. : Academia, 1999. - 786 s.

5. Neylor K. Kak postroit svoyu ekspertnuyu sistemu: Per. s angl. / K. Neylor - M. : Energoatomizdat, 1991, - $286 \mathrm{~s}$.

6. Mitina L. M. Psihologiya professionalnogo razvitiya uchitelya: [Tekst] / L. M. Mitina. - M. : Flinta : Moskov. psihologo-sotsial. in-t, 1998. -200 s.
7. Lytvynenko S. Formuvannia pedahohichnoi refleksii u protsesi profesiinoi pidhotovky maibutnikh uchyteliv v umovakh stupenevoi osvity / S. Lytvynenko. - [Elektronnyi resurs]. - Rezhym dostupu: http://irbis-nbuv.gov.ua/cgibin/irbis_nbuv/cgiirbis_64.exe?C21COM=2\&I21DBN $=U J R N \& P 21 D B N=U J R N \& I M A G E \_F I L E \_D O W N L$ OAD=1\&Image_file_name=PDF/Npd_2013_1.2_4.pd f -Data zvernennia: 17.06.2017.

8. Naznachilo E. V. Razvitie informatsionnoanaliticheskoy kompetentnosti prepodavatelya $\mathrm{V}$ protsesse nepreryivnogo pedagogicheskogo obrazovaniya: dis. ... kand. ped. nauk: spets. 13.00.08 / Naznachilo Elena Valerevna; Magnitogorskiy gos. un-t. - Magnitogorsk, 2003. - 193 c.

9. Moreva N. A. Tehnologii professionalnogo obrazovaniya. Ucheb. posobie dlya stud. vyissh. ucheb. zavedeniy / N. A. Moreva. - M. : Akademiya, 2005. - $432 \mathrm{~s}$.

10. Gaydamak E. S. Razvitie informatsionno-analiticheskoy kompetentnosti buduschego magistra fiziko-matematicheskogo obrazovaniya: dis. ... kand. ped. nauk: 13.00.02 / Gaydamak Elena Sergeevna; Omskiy gos. ped. un-t. - Omsk, 2006. - 214 s. 